\title{
Appraising the Frontiers and Limits of the Inter-American Human Rights System and Its Relevance to International Human Rights Law
}

\author{
Enya Nwocha (1) \\ Faculty of Law, Ebonyi State University, Abakaliki, Nigeria \\ Email: nwochaenyaeni@gmail.com
}

How to cite this paper: Nwocha, E. (2019). Appraising the Frontiers and Limits of the Inter-American Human Rights System and Its Relevance to International Human Rights Law. Beijing Law Review, 10, 178-195. https://doi.org/10.4236/blr.2019.101011

Received: December 30, 2018

Accepted: March 1, 2019

Published: March 4, 2019

Copyright ( 2019 by author(s) and Scientific Research Publishing Inc. This work is licensed under the Creative Commons Attribution International License (CC BY 4.0).

http://creativecommons.org/licenses/by/4.0/

\begin{abstract}
The Inter-American human rights system is one of the major regional human rights systems globally. In spite of the availability of human rights instruments in the region, some of which are legally binding, the spate of human rights abuse still leaves a sad commentary. The objective of this paper therefore is to take a critical survey of the human rights instruments in the region with a view to assessing their strengths and constraints. The method of research is basically doctrinal and utilizes the major human rights instruments in the region such as the Charter of the Organization of American States (OAS), the American Declaration of the Rights and Duties of man, and the American Convention on Human Rights in its evaluation. It is the finding of the paper that the Inter-American system indeed has a number of positive features such as the emphasis placed on democratic governance and third party interventions in the adjudicatory process among others. The paper has also identified a number of weaknesses in the system including that the Inter-American Commission lacks the power to refer a case to the Inter-American Court where the State concerned has not ratified the American Convention on Human Rights; and further, the Commission's recommendations are not legally binding. Therefore, the paper recommended among other things that the Commission be able to transmit a case directly to the Court whether or not the party concerned has ratified the American Convention.
\end{abstract}

\section{Keywords}

Human Rights Instruments, Inter-American System, Contentious Jurisdiction, Complaint Procedure, Advisory Opinion, Obligatory Judicial Decision 


\section{Introduction}

Human rights have been defined in a number of terms. They are those claims made by man for themselves or on behalf of other men, supported by some theory, which concentrates on the humanity of man, on man as a human being and a member of humankind (Dowrick, 1979). Human rights are also those rights which appertain to individuals as human beings and which they expect the society they live or reside in should respect irrespective of their color, race, religion, sex or other distinctions (Umozurike, 2004). Human rights instruments refer to international or regional treaties and conventions for human rights as well as domestic human rights legislation. The world is by geographical convenience grouped into regions and sub-regions as the case may be. Taking a clue from the United Nations after the adoption of the Universal Declaration of $\mathrm{Hu}$ man Rights in 1948, most regions of the world made bold efforts to crystallize human rights within their regions for a greater and progressive impact of its widely acknowledged gains. This was so when the United Nations appeared to have gone into slumber over practical steps in the enforcement of international human rights after its conclusion of the Universal Declaration of Human Rights which spirit and letters were merely hortatory and inspirational at the time of its adoption. The world therefore yearned for more stringent and binding international law of human rights. The European system, inter-American system, and the African system of human rights are among major regional human rights systems with definite human rights frameworks that have contributed in large measures to the present body of international human rights law and practice. Hence, this paper is an evaluation of the inter-American system of human rights with a view to determining its strengths and weaknesses as well as its overall input to global human rights.

The American human rights system is anchored on three significant documents: the Charter of the Organization of American States (O.A.S.), the American Declaration of the Rights and Duties of Man, and the American Convention on Human Rights. The Organization of American States is a regional inter-governmental organization constituted by about 35 sovereign States of the Americas. ${ }^{1}$ The organization is not only concerned with the resolution of disputes and peacekeeping but also with human rights. It discharges its functions through various organs such as the General Assembly and the Permanent Council. The General Assembly formulates policies of the Organization and each member has one vote in the Assembly. The Permanent Council takes decisions in periods when the General Assembly is not in session (Caron, 2004). The inter-American system has made significant contributions to global human rights and this paper is intended to appraise its frontiers and constraints in this connection.

${ }^{1}$ The members include Antigua and Barbuda, Argentina, The Bahamas, Barbados, Belize, Bolivia, Brazil, Canada, Chile, Colombia, Costa Rica, Cuba, Dominica, Dominican Republic, Ecuador, El Salvador, Grenada, Guatemala, Guyana, Haiti, Honduras, Jamaica, Mexico, Nicaragua, Panama, Paraguay, Peru, St. Kitts and Nevis, St. Lucia, St. Vincent and Grenadines, Suriname, Trinidad and Tobago, United States of America, Uruguay, and Venezuela. 


\section{Literature Review}

According to Umozurike (2004), some of the landmarks of the American system include the prohibition of the collective expulsion of aliens under the convention and the encouragement of progressive development of the economic, social and cultural rights implicit in the charter of the Organization of American States. Again, the Inter-American Commission on Human Rights has powers regarding all member states of the Organization of American States, not just those that have ratified the convention (Shaw, 1997). The Charter of the Organization of American States (OAS) was drawn up and opened for signature in 1948 in Bogota, Colombia. It entered into force in 1951 and is binding on all members of the OAS. Aside of a few references to human rights, the Charter perse cannot be described as a human rights instrument. The first reference is in Article 3 (j) now Article $3(\mathrm{k})$ providing that the American States proclaim the fundamental rights of individuals without distinction as to race, nationality, creed, or sex among the principles to which they are committed. The second reference appears in Article 13, now Article 16, declaring that each State has the right to develop its cultural, political and economic life freely and naturally. It further prescribes that in this free development, the State shall respect the rights of the individual and the principles of universal morality. The Charter which has undergone a number of amendments, ${ }^{2}$ did not define the fundamental rights of the individual mentioned under Article 3, nor did it create any institution to promote their observance. In spite of the shortcomings of the O.A.S Charter, the same diplomatic conference which adopted the Charter also proclaimed the American Declaration of the Rights and Duties of Man (Shaw, 1997). The American Declaration of the Rights and Duties of Man was adopted under Resolution XXX by the Ninth International Conference of American States held in Bogota, Colombia between March 30 to May 2, 1948, predating the Universal Declaration of Human Rights by a few months. The preamble recognized that all men are born free and equal in dignity and in rights, and being endowed by nature with reason and conscience, they should conduct themselves as brothers one to another.

The American Declaration proclaims a list of twenty-seven human rights and ten duties of man. The rights include: right to life; liberty and personal security; right to equality before the law; right to religious freedom and worship; freedom of expression and dissemination of information; right to protection of honor, personal reputation, and private and family life; right to a family and to the protection thereof; right to protection for mothers and children; right to residence and movement; right to inviolability and transmission of correspondence; right to the preservation of health and to well-being; right to education; right to the benefits of culture; right to work and to fair remuneration; right to leisure time and to the use thereof; right to social security; right to recognition as juridical personality and of civil rights; right to fair trial; right to nationality; right to vote

${ }^{2}$ It was amended by the Protocol of Buenos Aires concluded in 1967 and came into effect in 1970; The Protocol of Cartagena de Indias, Columbia concluded in 1985 and entered into force in 1988; and subsequently by the Protocols of Washington and Managua. 
and to participate in government; right of assembly; right of association; right to property; right of petition; right to protection from arbitrary arrest; right to due process of law; and right of asylum. ${ }^{3}$ Article XXVIII provides a general caveat that the rights of man are limited by the rights of others, the security of all, and the just demands of the general welfare and the advancement of democracy.

Chapter two of the Declaration states the duties of man to include: duty of the individual so to conduct himself in relation to others that each and everyone may fully form and develop his personality; duty of every person to aid, support, educate and protect his minor children and duty of children to honor their parents always and to aid, support and protect them when they need it; duty of every person to acquire at least an elementary education; duty of every person to vote in the popular elections of the Country of which he is a national when he is legally capable of doing so; duty of every person to obey the law and other legitimate commands of the authorities of his Country and those of the Country in which he may be; duty of every able-bodied person to render whatever civil and military service his Country may require for its defense and preservation and in case of public disaster to render such services as may be in his power, and to hold any public office to which he may be elected by popular vote in the State of which he is a national; duty of every person to co-operate with the State and the Community with respect to social security and welfare in accordance with his ability and with existing circumstances; duty of every person to pay the taxes established by law for the support of public services; duty of every person to work, as far as his capacity and possibilities permit, in order to obtain the means of livelihood or to benefit his Community; and finally, duty of every person to refrain from taking part in political activities that, according to law, are reserved exclusively to the citizens of the State in which he is an alien. ${ }^{4}$

At the time it was proclaimed in 1948, the Declaration was not intended to have legal effect. Accordingly, no apparatus was established at the time of its adoption to implement its content. However, over the years its legal status began to change mainly due to the human rights practice of the OAS States such that today it is viewed in retrospect, as the normative instrument that embodies the authoritative interpretation of the fundamental rights of the individual which Article 3 (k) of the OAS Charter proclaims (Buergenthal, 1995). This view has been affirmed in a subsequent decision of the Inter-American Court of Human Rights which found that for the member States of the Organization of American States, the Declaration is the text that defines the human rights referred to in the Charter, and that the Declaration is for these States a source of international obligations related to the Charter of the Organization. ${ }^{5}$

It was much later in 1959 that the Fifth Meeting of Consultation of Ministers ${ }^{3}$ See chapter one particularly Articles I-XXVII.

${ }^{4}$ Articles XXIX-XXXVIII.

${ }^{5}$ See the Court's Advisory Opinion in the Case Concerning the Adherence of the State of Canada to the American Convention on Human Rights (1989) Oc-10/89.1-A Court H.R Series A: Judgments and Opinions No. 10 Para 45. 
of Foreign Affairs mandated the establishment of the Inter-American Commission on Human Rights which the O.A.S Permanent Council complied with in 1960 by adopting the Statute of the Commission and electing the first seven Commission members. The Council designated the Commission as an autonomous entity of the O.A.S that was to function to promote respect for human rights. ${ }^{6}$ Specifically, Article 2 stated that for the purpose of the Statute establishing the Commission, human rights were to be understood to be those set forth in the American Declaration of the Rights and Duties of Man. The adoption of the Statute coupled with the strength of its language inspired the transformation of the Declaration into the important normative instrument it has become.

The American Convention on Human Rights is a product of the Inter-American Specialized Conference on Human Rights held in San Jose, Costa Rica on November 22, 1969. It opened for signature on the above date and came into force almost a decade later on July $18,1978 .{ }^{7}$ By the preamble to the Convention, the Parties re-affirm their intention to consolidate in the American hemisphere and within the framework of democratic institutions, a system of personal liberty and social justice based, on respect for the essential rights of man. The Convention equally recognized the principles set forth in the Charter of the Organization of American States, the American Declaration of the Rights and Duties of Man, and the Universal Declaration of Human Rights. The Convention is segmented into eleven chapters and eighty-two articles.

\section{The American Convention on Human Rights}

This is by far the strongest and most potent human rights treaty in the American hemisphere to date. Unlike some of its predecessors, its provisions are binding and obligatory. Chapter 1, containing Articles 1 and 2, is a general provision mandating States Parties to respect the rights and freedoms recognized in the Convention and to ensure to all persons subject to their jurisdiction the free and full exercise of those rights and freedoms without any discrimination based on reasons of race, color, sex, language, religion, political or other opinion, national or social origin, economic status, birth, or any other social condition; and to ensure compliance with the Convention by domestic legislative or other measures necessary to give effect to those rights or freedoms.

Chapter II dealing on civil and political rights is contained in Articles 3 to 25 . Article 3 provides that every person has a right to recognition as a person before the law. ${ }^{8}$ Article 4 secures the right to life which begins at the point of concep${ }^{6}$ Article 1.

${ }^{7}$ Parties to the Convention include: Argentina, Barbados, Bolivia, Brazil, Chile, Colombia, Costa Rica, Dominica, Dominican Republic, Ecuador, El Salvador, Grenada, Guatemala, Haiti, Honduras, Jamaica, Mexico, Nicaragua, Panama, Paraguay, Peru, Suriname, Trinidad and Tobago, Uruguay, and Venezuela. One of the setbacks of this Convention is that the United States, Canada and some smaller English speaking Caribbean Countries are not Parties. Although the United States signed the Convention, the U.S. Senate declined to give consent to its ratification, a request sent by President Jimmy Carta. To date such request has never been renewed by subsequent U.S. administrations.

${ }^{8}$ Article 1 (2) states that person means every human being. 
tion. In Countries that have not abolished the death penalty ${ }^{9}$, it may be imposed only for the most serious crimes and pursuant to a final judgment rendered by a competent Court and in accordance with a law establishing such punishment, enacted prior to the commission of the crime. Death penalty shall not be re-established in States that have abolished it and under no circumstances shall it be inflicted for political offences or related common crimes. It shall also not be imposed upon persons who at the time the crime was committed were under 18 years of age or over 70 years of age, or upon pregnant women. And every person condemned to death shall have the right to apply for amnesty, pardon, or commutation of sentence which may be granted in all cases. While such application or petition is pending before the competent authority, the applicant shall not suffer execution.

Article 5 protects the right to humane treatment and, accordingly, no one shall be subjected to torture or to cruel, in-human, or degrading treatment or punishment and all persons deprived of their liberty shall be treated with respect for the inherent dignity of the human person. Article 6 guarantees freedom from slavery and involuntary servitude and as such no one shall be required to perform forced or compulsory labor except as punishment for crime of which an accused has been found guilty under due process of law. Generally forced or compulsory lab our does not include work or service normally required of a person imprisoned in execution of a sentence or formal decision passed by the competent judicial authority; ${ }^{10}$ military service or national service as applicable; service exacted in time of danger or calamity that threatens the existence or the well-being of the community; or work or service that forms part of normal civic obligations.

Article 7 guarantees the right to personal liberty and forbids arbitrary arrest or imprisonment. No one shall be detained for debt. This principle however does not prejudice the orders of a competent judicial authority issued for non-fulfillment of duties of support. Articles 8 and 9 protect the right to fair trial and freedom from ex post facto laws respectively. By Article 10, every person has the right to be compensated in accordance with the law in the event he has been sentenced by a final judgment through a miscarriage of justice. Right to privacy is secured by Article 11 while freedom of conscience and religion and freedom of thought and expression are protected under Articles 12 and 13 respectively. According to Article 14, anyone injured by inaccurate or offensive statements or ideas disseminated to the public in general by a legally regulated medium of communication has the right to reply or to make a correction using the same communications outlet, under such conditions as the law may establish. The correction or reply shall not in any case remit other legal liabilities that may have been incurred. And for the effective protection of honor and reputation, every

${ }^{9}$ A Protocol on the Abolition of the Death Penalty was adopted on 8. June, 1990. It enters into force for States upon deposit of the instrument of ratification or accession.

${ }^{10} \mathrm{~A}$ person under such labor shall not be placed at the disposal of any party, company, or juridical person. 
publisher, and every newspaper, motion pictures, radio, and television Company, shall have a person responsible who is not protected by immunities or special privileges.

Articles 15 and 16 protect rights to assembly and freedom of association respectively. However, the rights to freedom of association and to assembly are both subject to limitations established by law as may be necessary in a democratic society, in the interests of national security, public safety or public order, or for protection of public health or morals or the rights and freedoms of others. Further, Article 16 does not bar the imposition of legal restrictions, including even deprivation of the exercise of the right of association on members of the armed forces and the police. Articles 17 and 18 recognize the rights of the family and right to a name respectively. By Article 19, every minor child has the right to the measures of protection required by his condition as a minor on the part of his family, society, and the State. And by Article 20, every person has a right to a nationality and to the nationality of the State in whose territory he was born if he does not have the right to any other nationality. No one shall be arbitrarily deprived of his nationality or of the right to change it.

Article 21 protects the right to property and declares that usury and other forms of exploitation of man by man shall be prohibited by law. Article 22 guarantees freedom of movement and residence. In that wise, every person lawfully in the territory of a State Party has the right to move about in it and to reside in it subject to the provisions of the law. Every person has the right to leave any Country freely, including his own, and no one can be expelled from the territory of the State of which he is a national or be deprived of the right to enter it. In no case may an alien be deported or returned to a Country, regardless of whether or not it is his Country of origin, if in that Country his right to life or personal freedom is in danger of being violated because of his race, nationality, religion, social status, or political opinions.

Articles 23 and 24 protect the rights to participate in government and to equal protection of the law respectively. Article 25 recognizes the right to judicial protection wherein everyone has the right to simple and prompt recourse, or any other effective recourse, to a competent Court or tribunal for protection against acts that violate his fundamental rights recognized by the Constitution or laws of the State concerned or by the American Convention, even though such violation may have been committed by person acting in the course of their official duties. Further, State Parties to the Convention undertake to ensure that any person claiming such remedy shall have his rights determined by the competent authority provided for by the legal system of the State; to develop the possibilities of judicial remedy; and to ensure that the competent authorities shall enforce such remedies when granted.

Chapter III contains only Article 26 and deals with economic, social, and cultural rights. Here, the States Parties undertake to adopt measures, both internally and through international cooperation, especially those of an economic and 
technical nature, with a view to achieving progressively, by legislation or other appropriate means, the full realization of the rights implicit in the economic, social, educational, scientific, and cultural standards set forth in the Charter of the Organization of American States as amended by the Protocol of Buenos Aires. ${ }^{11}$

Chapter IV containing Articles 27, 28, 29, 30, and 31 describes the circumstances in which certain rights can be temporarily suspended such as during states of emergency, and the formalities to be followed for such suspension to be valid. Chapter V containing only Article 32 confirms the balance between rights and duties enshrined in the earlier American Declaration of the Rights and Duties of Man, pointing out that individuals have responsibilities as well as rights. Chapters VI, VII, VIII, and IX contain provisions for the creation and operation of the two bodies responsible for overseeing compliance with the Convention namely, the Inter-American Commission, based in Washington D.C., United States; and the Inter-American Court, headquartered in San Jose, Costa Rica. Chapter X deals with mechanisms for ratifying the Convention, amending it or placing reservations in it, or denouncing it. Chapter XI sets forth various transitory provisions relating to the first election of the members of the Inter-American Commission on Human Rights and the Inter-American Court of Human Rights.

After a couple of decades that it came into force, the American Convention on Human Rights developed three additional Protocols to supplement some of its provisions (Umozurike, 2005). The Additional Protocol to the American Convention on Human Rights in the Area of Economic, Social, and Cultural Rights more commonly known as the Protocol of San Salvador was opened for signature in the city of San Salvador, El Salvador on November 17, 1988, to give effect to the provisions of Article 26 of the American Convention. It entered into force on November 16, 1999, and has to date been ratified by 14 nations. Article 26 of the American Convention expresses the general commitment of State Parties to adopt measures with a view to the full realization of economic, social, and cultural rights. However, the Protocol represents an attempt to take the inter-American human rights system to a higher level by enshrining its protection of second generation rights in the economic, social, and cultural spheres in a binding document. The Protocol's provisions cover such areas as the right to work, the right to health, the right to food, and the right to education. ${ }^{12}$ It is further noted that rather than assuming immediate obligations States undertake to

${ }^{11}$ In 1998 the Organization adopted the Additional Protocol to the American Convention on Human Rights in the Area of Economic, Social and Cultural Rights, also known as the Protocol of San Salvador.

${ }^{12}$ Ratification of the Protocol of San Salvador is only open to States that have ratified the American Convention. The following Countries have ratified the Protocol to date namely, Argentina (30 ${ }^{\text {th }}$ June, 2003), Bolivia (12 ${ }^{\text {th }}$ July, 2006), Brazil ( ${ }^{\text {th }}$ August, 1996), Dominican Republic ( $21^{\text {st }}$ January, 1978), Ecuador ( $8^{\text {th }}$ December, 1997), El Salvador $\left(20^{\text {th }}\right.$ July, 1978), Grenada (14 ${ }^{\text {th }}$ July, 1978), Guatemala (27 April, 1978), Mexico ( $8^{\text {th }}$ March, 1996), Panama (28 ${ }^{\text {th }}$ October, 1992), Paraguay $\left(28^{\text {th }}\right.$ May, 1997), Peru (17 May, 1995), Suriname (28 $8^{\text {th }}$ February, 1990), Uruguay (21 $1^{\text {st }}$ December, 1995). 
implement their obligations progressively. ${ }^{13}$

Progressive implementation is, nonetheless, an obligation. In the Five Pensioner ${ }^{2}$ Case ${ }^{14}$ the Inter-American Court of Human Rights had the challenge to determine the scope and content of the duties of States with respect to the progressive implementation of social, economic, and cultural rights. The alleged victims argued that a decision by the Government of Peru to modify pension payments which resulted in a reduction of the payments violated, among others, their right to the progressive development of their economic, social, and cultural rights under Article 26 of the American Convention as interpreted in the light of the Protocol of San Salvador. In its judgment of February 28, 2003, the Court held that economic, social, and cultural rights that have both an individual and a collective dimension must be assessed in reference to the general situation prevailing in the Country. In the Court's opinion, the five pensioners were a very small group and were not necessarily representative of a general situation as to hold Peru in violation of Article 26 of the American Convention. ${ }^{15}$ Some provisions of the Protocol are nevertheless of immediate application. Thus, violations of the right to organize and to join unions, national federations of unions or international trade union organizations, protected under Article 8 (a) of the Protocol, as well as violations of the right to education can be brought to the attention of the Inter-American Commission through the individual petition mechanism ${ }^{16}$ and may subsequently be brought before the Inter-American Court.

The Additional Protocol to the American Convention on Human Rights to Abolish the Death Penalty was adopted at Asuncion, Paraguay on June 8, 1990. It expands upon Article 4 of the American Convention and its ratification is open only to States Parties to the American Convention. ${ }^{17}$ Signing this Protocol formalizes a State's solemn commitment to refrain from using capital punishment in any peacetime circumstance. The only reservation allowed at the time of ratification is the application of the death penalty in wartime for certain crimes. According to Article 2 (1) of the Protocol:

No reservations may be made to this Protocol. However, at the time of ratification or accession, the States Parties to this instrument may declare that they reserve the right to apply the death penalty in wartime in accordance

\footnotetext{
${ }^{13}$ By Article 1 of the Protocol, the States Parties to the American Convention on Human Rights undertake to adopt the necessary measures, both domestically and through international cooperation especially economic and technical to the extent allowed by their available resources, and taking into account their degree of development, for the purpose of achieving progressively and pursuant to their internal legislations, the full observance of the rights recognized in the Protocol.

${ }^{14}$ (2003) OEA /Ser. L/V/11.213 Doc. 17; see also Carlos Torres Benvento et al V. Peru (1999) OEA/Ser. L/V/11.106, Doc. 6 rev., April 13, 1999.

${ }^{15}$ Nevertheless the Court made a finding that Peru violated the pensioners' right to property (Article 21 of the Convention) their right to judicial protection (Article 25), and its obligation to ensure respect of the rights guaranteed under the Convention (Article 1.1).

${ }^{16}$ Article 19 (6) of the Protocol.

${ }^{17}$ Article 4 of the American Convention already placed severe restrictions on the States' ability to impose the death penalty and made it applicable only for the most serious crimes, no reinstatement once abolished; not to be used for political offences or common crimes; not to be used against those aged under 18 or over 70 , or against pregnant women.
} 
with international law, for extremely serious crimes of a military nature.

This exception must however be provided for in domestic law and its application is subject to the proviso that a State making the reservation shall upon ratification or accession, inform the Secretary-General of the Organization of American States of the pertinent provisions of its national legislation applicable in wartime, and further, notify the Secretary-General of the beginning or end of any state of war in effect in its territory. ${ }^{18}$ In line with Article 3 (1) the Protocol is open for signature and ratification by State Parties to the American Convention on Human Rights. And by Article 4, the Protocol shall enter into force among the States that ratify or accede to it. To date, eleven member States of the Organization of American States have ratified the Protocol. ${ }^{19}$ Again, in 1967 the Protocol of Amendment to the Charter of the Organization of American commonly referred to as the Protocol of Buenos Aires, was adopted and entered into force on $12^{\text {th }}$ March, 1970. The protocol amended the machinery of the OAS and of the American Convention. In a few words, the American Convention on Human Rights has comprehensive provisions protecting various elements of civil and political rights as has been demonstrated in the foregoing.

\section{Merits of the Inter-American Human Rights System}

The Inter-American system lays special emphasis on democratic governance which is the bedrock for the flourishing of human rights. The system is hostile to dictatorial regimes which had become pervasive in the Latin American Countries at the time the Charter of the Organization of American States was adopted in 1948 (Schwelb, 1964). Under the terms of Article 19 of the Charter, non-democratic governments can be prevented from exercising their rights as members of the Organization of American States. It provides that:

An unconstitutional interruption of the democratic order or an unconstitutional alteration of the constitutional regime that seriously impairs the democratic order in a member State, constitutes, while it persists, an insurmountable obstacle to its government's participation in sessions of the General Assembly, the Meeting of Consultation, the Councils of the Organization, the Specialized Conferences, the Commissions, Working Groups, and other bodies of the Organization.

Again, the Protocol of Washington of 1992 provided for the suspension of States members whose democratically elected government has been overthrown. Furthermore, in 2002, the Organization of American States adopted a Democratic Charter which illustrates its commitment to strengthen democracy in Latin America. Under Article 2 of the Charter:

The effective exercise of representative democracy is the basis for the rule of ${ }^{18}$ Article 2 (2) and (3) of the Protocol.

${ }^{19}$ Namely: Panama (27 $7^{\text {th }}$ June, 1991), Venezuela (24 ${ }^{\text {th }}$ August, 1992), Uruguay ( $8^{\text {th }}$ February, 1994), Brazil (31 $\left.{ }^{\text {st }} J u l y, 1996\right)$, El Salvador ( $4^{\text {th }}$ May, 1997), Guatemala (30 ${ }^{\text {th }}$ March, 1998), Argentina (18 ${ }^{\text {th }}$ June, 2008), Ecuador ( $4^{\text {th }}$ August, 2008), Paraguay ( $31^{\text {st }}$ October, 2000), Nicaragua (24 $4^{\text {th }}$ March, 1999), Mexico (28 th June 2007). 
law and of the constitutional regimes of the member States of the Organization of American States. Representative democracy is strengthened and deepened by permanent, ethical, and responsible participation of the citizenry within a legal framework conforming to the respective constitutional order.

Another unique characteristic of the American Convention on Human Rights is that the right of individuals to bring alleged violations by States Parties to the Convention of the rights it protects to the attention of the Inter-American Commission can be exercised without any formal acceptance of the Commission's jurisdiction. This was confirmed by the Inter-American Court in: In the Matter of Viviano Gallaro et al. (Robinson, 2000). ${ }^{20}$ This waiver makes the Commission more accessible to a wider range of victims of human rights abuse. It is further noted that the Inter-American Commission was a key player in the struggle against the repressive regimes in the American hemisphere and today continues to provide recourse to people who have suffered human rights violations.

Similarly, the Inter-American Court's advisory jurisdiction is unique in several ways. In addition to the Inter-American Commission and other authorized bodies of the Organization of American States, it extends to all member States of the Organization, whether Party to the Convention or not, and even if they have not recognized the jurisdiction of the Court over contentious matters. This is the largest advisory jurisdiction of any international Court. States cannot make requests for advisory opinions to either the European Court of Human Rights or the International Court of Justice. As a matter of fact, in the European system, only the Committee of Ministers of the Council of Europe can ask the European Court of Human Rights for an advisory opinion. ${ }^{21}$ At the United Nations level, the advisory jurisdiction of the International Court of Justice in the Hague extends only to the General Assembly and the Security Council, as well as other United Nations organs and specialized agencies authorized by the General Assembly. ${ }^{22}$ Members of the Organization of American States may consult the Court regarding the interpretation not only of the Convention but also of any other treaty pertaining to the protection of human rights in the Americas. ${ }^{23}$ They

\footnotetext{
${ }^{20}$ Inter-Am. CtHR Decision of 13 November 1981, Ser. A, No. G 101/81 (supra).

${ }^{21}$ Article 1 of Protocol 2 to the European Convention for the Protection of Human Rights and Fundamental Freedoms, signed at Strasbourg on $6^{\text {th }}$ May, 1963, and entered into force on $21^{\text {st }}$ September, 1970. This Protocol conferred upon the European Court of Human Rights competence to give advisory opinions.

${ }^{22}$ Article 96 of the Charter of the United Nations, signed in San Francisco on $26^{\text {th }}$ June, 1945, and entered into force on $24^{\text {th }}$ October, 1945.

${ }^{23}$ Article 64 of the American Convention; Interpretation of the American Declaration of the Rights and Duties of Man within the Framework of Article 64 of the American Convention of Human Rights (Inter. Am. Ct. HR, Advisory opinion OC-10/89 of $14^{\text {th }}$ July, 1989, Ser. A, no. 10; Legal Status and Human Rights of the Child, Advisory Opinion, OC-17/2002 of 28 August 2002, Ser. A, no. 7; Other Treaties subject to the Consultative Jurisdiction of the Court (Article 64 of the American Convention Human Rights), Inter-Am. Ct. HR, Advisory Opinion OC-1/82 of 24 September, 1982, Ser. A, No. 1; Right to Information on Consular Assistance within the Framework of the Guarantees of Legal Due Process, Inter-Am. Ct. HR, Advisory Opinion OC-16/99 of 1 October, 1999, Ser. A. No. 16; The Word "Laws" in Article 30 of the American Convention on Human Rights, Inter-Am. Ct HR, Advisory Opinion OC-6/86 of $9^{\text {th }}$ May, 1986, Ser. A, no. 6 all accessed on 10/5/2018 at: http://www.wcl.america.edu/hrbrief/07/2newsasystem.cfm.
} 
can also consult the Court on the compatibility of their domestic laws, bills, and proposed legislative amendments. ${ }^{24}$ Furthermore, there exists a procedure for third party intervention in the inter-American system. It is granted that individuals and groups who feel that their rights have been violated may petition the Inter-American Commission for redress, once they have exhausted all the remedies available to them at the national level. The special feature here is that apart from those directly involved as victims of the abuse, anyone aware of such a violation may petition the Inter-American Commission. Under Article 23 of the Commission's Rules of Procedure, any person or group of persons or non-governmental entity legally recognized in one or more of the member States of the Organization of American States may submit petitions to the Commission, on their own behalf or on behalf of third persons, concerning alleged violations of a human right recognized in, as the case may be, the American Declaration of the Rights and Duties of Man, the American Convention on Human Rights and other human rights legislations operative within the American hemisphere. This feature of the inter-American system has been reflected in even national legislations. In Nigeria, the Fundamental Rights (Enforcement Procedure) Rules 2009, in its Preamble 3 (e) provides that the Court shall encourage and welcome public interest litigation in the human rights field and no human rights case may be dismissed or struck out for want of locus standi. In particular human rights activists, advocates or groups as well as any non-governmental organizations may institute human rights application on behalf of any potential applicant. This represents an innovative development in the area of human rights litigation and the trail was blazed by the inter-American system. Again, the inter-American system has simplified the procedure for bringing applications before the Inter-American Commission. Although an electronic form is available on the Internet site of the Inter-American Commission on Human Rights, its use is not mandatory. In fact, the petition may take the form of a simple letter stating the facts of the situation denounced, the identity of the petitioner if the petition is not signed by the alleged victim, and what remedies have been pursued at the national level. What is more, the alleged victim or his representative in interest does not have to travel to Washington D.C. headquarters of the Court to present the petition as the same may be sent by mail or fax thus beating down the cost of litigation in the interest particularly of the poor.

The system creates ample opportunity for States to make amends in that if the preliminary report drafted by the Inter-American Commission establishes violations, it sets a deadline of three months for compliance. The purpose of this preliminary report is to give the State concerned ample warning and time to redress the situation before initiating judicial proceedings. This is a good development because the State is thus saved the diplomatic and political embarrassment that may be the outcome of a final determination of the Inter-American Court. It al${ }^{24}$ See Proposed Amendments to the Naturalization Provisions of the Constitution of Costa Rica, OC-4/84, Ser. A. No. 4; Compatibility of Draft Legislation with Article 8 (2) (h) of the American Convention on Human Rights, OC-12/91, Ser. A, no. 12, accessed on 10/5/2018 at http://www.wcl.america.edu/hrbrief/07/2newsasystem.cfm. 
so creates interim preservative measures. For at any stage of the proceedings before the Inter-American Court, the parties may ask the Court for provisional measures to preserve any threatened rights, or the Court may take such measures suomotu in cases of the extreme gravity or urgency and whenever it is necessary in order to avoid irreparable harm to persons involved in the case. If the Court is not sitting, the President can make the Order. ${ }^{25}$ The jurisprudence of the Inter-American Court reveals that provisional measures were frequently ordered for between July 2000 and June 2001. For instance, they were ordered in 13 cases generally to protect the lives of witnesses and victims of the alleged violations. ${ }^{26}$ This innovation, again, has been borrowed into national legislations. Order III Rule 3 of the Fundamental Rights (Enforcement Procedure) Rules, 2009, of Nigeria provides that the Court may if satisfied that exceptional hardship may be caused to the Applicant before the service of the application especially when the life or liberty of the applicant is involved, hear the applicant $e_{x}$ parte upon such interim reliefs as the justice of the application may demand. There is equally an opportunity for amicus curriae. There is no formal process for requesting permission to intervene, an indication of its simplicity. Parties wishing to intervene merely send a brief to the Court asking it to take it into consideration. Individuals and organizations that have a particular interest in the outcome of the case have made such requests and the Court has accepted amicus briefs on several occasions. ${ }^{27}$ It has however refused amicus in some cases. ${ }^{28}$ Again this is reflected under Order XIII Rule 7 of the Nigerian Fundamental Rights (Enforcement Procedure) Rules providing that amicicuriae may be encouraged in human rights applications and may be heard at any time if the Court's business allows it.

The inter-American system does not allow derogation on basic rights. Although, Article 27 of the American Convention on Human Rights allows the States Parties to derogate from their obligations in time of war, public danger, or other emergency that threatens their independence or security. Derogation is not, however, permitted from the application of the more basic human rights which the Convention guarantees, namely, Article 3 (right to juridical personality; Article 4 (right to life); Article 5 (right to humane treatment); Article 6 (freedom from slavery); Article 9 (freedom from ex post facto laws); Article 12

${ }^{25}$ Article 25 (1) and (4) of the Rules of Procedure of the Inter-American Court; Order of the President of the Inter-American Court of Human Rights of April 7, 2000, Provisional Measures in the Constitutional Court case, accessed on 10/5/2018 at: http://www.wcl.america.edu/hrbrief/07/2newsasystem.cfm.

${ }^{26}$ Serie E: Provisional Measures, No. 3, Compendium July 2000-June 2001, accessed on 10/5/2018 at http://www.wcl.america.edu/hrbrief/07/2newsasystem.cfm.

${ }^{27}$ The Inter-American Press Association intervened in the Bronstein case, several aboriginal Organizations including the Assembly of First Nations intervened in the case of the Mayagna (Sumo) Community of Awas Tingni; the International Commission of Jurists intervened in the Bamaca Velasquez case, Rights International intervened in the Benavides Cevallos case and in the Suarez Rosero case.

${ }^{28}$ See for example the Papiagua Morales et al. vs. Guatemala, Provisional Measures, Inter-Am. Ct HR, Order of 27 November 1998, Ser. E, accessed on 10/5/2018 at: http://www.wcl.american.edu/hrbrief/07/2newsasystem.cfm. 
(freedom of conscience and religion); Article 17 (rights of the family); Article 18 (right to a name); Article 19 (rights of the child); Article 20 (right to nationality); and Article 23 (right to participate in government). Furthermore, the judicial guarantees essential for the protection of such rights are also non-derogable and non-suspendable. The system also protects life from moment of conception. Article 4 (1) of the American Convention on Human Rights guarantees the right to life in general from the moment of conception (Ezejiofor, 2005). The phrase from the moment of conception is a distinctive feature of the inter-American system. It broadens the horizon protected under the right to life and so is more comprehensive than what we have under other regional human rights regimes. ${ }^{29}$

The Inter-American Court of Human Rights remains today one of the boldest and most dynamic among international human rights Courts. Its advocacy is marked by a number of landmark decisions. In one of its first opinions, for example, the Court famously declared that modern human rights treaties, in general and the American Convention in particular, are not multilateral treaties of the traditional type concluded to accomplish the reciprocal exchange of rights for the mutual benefit of the contracting States. ${ }^{30}$ In effect, once a State has ratified a treaty it does not await the acceptance of such ratification by other states before it is bound by its obligations under the treaty. Of the contentious cases decided thus far the most important ones are the Honduran Disappearance cases which constitute the first ever international adjudication of charges implicating a State in a policy of forced disappearances (Barsh, 1986). These cases explore the obligations assumed by the States Parties under Article 1 (1) of the Convention as well as the difficult evidentiary issues that arise in disappearance cases. ${ }^{31}$

Furthermore, Article 14 of the American Convention on Human Rights grants a mandatory right of reply to persons who are victims of libelous publications. It states that anyone injured by inaccurate or offensive statements or ideas disseminated to the public in general by a legally regulated medium of communica-

\footnotetext{
${ }^{29}$ However, note that the Inter-American Commission held in Baby Boy vs. USA (Resolution 23/91, March 6, 1981, Annual Report of the Inter-American Commission on Human Rights 1980-1981), otherwise called the Baby Boy case that the terms in general in the provision were added as a result of a compromise among OAS member States, and that Article 4 (1) did not impose any specific obligation on States with respect to abortion. The issue is yet to come before the Inter-American Court which, when it does, will be faced with the resolution of the issue whether prohibiting or in extreme cases criminalizing abortion will not interfere with the right of women to life, security, equality, and conscience under international law. It must be noted that different nations react differently to the question of abortion. While Nigerian laws criminalize it (sections 232 to 234 of Penal Code Cap 89 LFN 1990 which deal with offences related to abortion), there is no legislation or regulation at the moment in Canada with respect to abortions. Thus the Supreme Court of Canada found in $R . V$. Morgentaler (1988, I.S.C.R 30), that the procedure created under section 251 of the Canadian Criminal Code for obtaining an abortion was incompatible with a woman's right to the security of her person.

${ }^{30}$ See Other Treaties Subject to the Consultative Jurisdiction of the Court, Inter-Am. Ct HR, Advisory Opinion OC-1/82 of 24 September 1982, Ser. A, No.1, accessed on 10/5/2018 at:

http://www.wcl.american.edu/hrbrief/07/2newsasystem.cfm.

${ }^{31}$ See FairenGarbi and Solis Corrales vs. Honduras (Merits) Inter-Am. Ct HR 15 March 1989, Ser. C No. 6; Godinez Cruz V. Honduras ( Merits), Inter-Am. Ct HR, 29 January 1989, Ser. C No.5; Velasquez Rodriguez V. Honduras (merits), Inter-Am. Ct. HR, 29 July 1988, Ser. C.No.4 accessed on 10/5/2018 at: http://www.wcl.american.edu/hrbrief/07/2newsasystem.cfm.
} 
tion has the right to reply or to make a correction using the same communications outlet, under such conditions as the law may establish; such correction or reply not foreclosing other legal liabilities that may have been incurred by the first publication. And for the effective protection of honor and reputation, every publisher, and every newspaper, motion picture, radio, and television Company, is mandated to appoint a responsible officer who is not protected by immunities or special privileges. While other international human rights treaties provide for freedom from degrading treatment and of expression none of them dealt specifically with right of reply to an unfair publication. ${ }^{32}$

\section{Constraints of the Inter-American System of Human Rights}

Notwithstanding the positive features of the inter-American human rights system, the system still leaves room for improvement and a number of abnormalities may be identified. First, there is inadequate publicity of human rights violations. The Reports of the Inter-American Court to the General Assembly of the Organization of American States have been criticized on the ground that the Assembly's resolutions on the Reports are tended to protect culprit governments from adverse publicity in that such resolutions are drafted in such a way as to either disguise the names of the Countries that were the subjects of these reports or to name them without taking note of the charges against them. ${ }^{33} \mathrm{~A}$ better approach would have been to adopt a stronger resolution that not only condemns perpetrators of abuses but exposes them and the malfeasance for which they are liable. In a morally conscious society the sanction of naming and shaming may prove to be a potent weapon. Second, we find a rather poor acceptance of the inter-American court's contentious jurisdiction. The individual petition procedure is beset by two weaknesses. The first has to do with the fact that where the petitions are directed against States which are not Parties to the Convention the Inter-American Court has no contentious jurisdiction to deal with them. Second, although the Commission transmits its decisions in these cases to the General Assembly, non-compliance by States with the decisions of the Commission in these cases consequently attracts little notice which waters down the effectiveness of the system. Third, there is widespread abuse of the federal clause in the American Convention. Article 28 of the American Convention creates a federal clause that has been criticized as creating an escape route to federal States to avoid their responsibilities under the Convention. Article 28 (1) States that where a State Party is constituted as a federal State, the national government of such State Party shall implement all the provisions of the Convention over whose subject matter it exercises legislative and judicial jurisdiction. Although ${ }^{32}$ Compare Article 19 International Covenant on Civil and Political Rights, 1966; Article 10 European Convention for the Protection of Human Rights and Fundamental freedoms, 1950; Article 9 African Charter on Human and Peoples' Rights, 1981.

${ }^{33}$ See Assembly Resolution 1269 (XXIV-O/94) OAS Gen. Ass. DOC. OEA/Ser. P. XX. O. 2 Vol.1 at 75 (1994); Assembly Resolution 1213 (XXIII-O/93), OAS Gen. Ass. DOC. OEA/Ser. P/XXIII. O. 2 Vol. 1 at 31 (1993). 
Article 28 (2) mandates the national government to take suitable measures in accordance with its Constitution and its laws to the end that the competent authorities of the constituent units may adopt appropriate provisions for the fulfillment of the Convention within their respective areas of legislative and judicial competence, this splitting of commitment is open to abuse and in most cases may result to passing of buck between the federal and constituent units to the detriment of the regional system.

Fourth, membership of both court and commission are not full time. Membership of both the Inter-American Commission and the Inter-American Court is not full-time. With a small permanent professional staff, effective enforcement of human rights is bound to experience a drag. Fifth, the Inter-American Commission may deal with inter-state complaints only if both States in addition to ratifying the Convention, have also recognized the inter-state jurisdiction of the Commission under Article 45 of the Convention. In adopting this approach, the American Convention departs from the more traditional scheme utilized by the European Convention, for example, which establishes an optional individual petition system and a mandatory inter-state complaint procedure. Sixth, there is absence of any specific mechanism to supervise the enforcement of the court's judgment. The Convention does not establish any specific mechanism to supervise the enforcement of the judgment of the Inter-American Court. Article 65 of the Convention states that to each regular session of the General Assembly of the Organization of American States, the Court shall submit, for the Assembly's consideration, a report on its work during the previous year, specifying, in particular, the cases in which a State has not complied with its judgments, and making any pertinent recommendations. The setback here is that the Assembly lacks the power to adopt resolutions that are legally binding on the member States. However, condemnatory resolutions by the Assembly do carry considerable political weight. Nevertheless, such resolutions have never come in a number

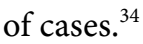

Seventh, the inter-American Commission lacks the power to refer case to Court where the concerned party has not ratified the American Convention. The process of examination by the Commission is essentially the same whether the petition alleges violations of the Declaration or of the Convention. The fundamental difference is that the jurisdiction of the Inter-American Court is based on the American Convention, not on the Charter of the Organization of American States, and it requires formal acceptance by States. Consequently, if the State concerned has not ratified the American Convention, or has ratified the Convention but has not recognized the jurisdiction of the Court, the Commission will not be able to refer the case to the Court and the process will end with the Commission's recommendations. Eightieth, although members of the Organiza-

\footnotetext{
${ }^{34}$ See the Honduran Disappearance cases: Velasquez Rodriguez (Supra) and Godinez Cruz (supra). The Honduran Disappearance cases were finally resolved in 1995 when the Honduran Government headed by a former President of the Inter-American Court accepted voluntarily to pay the remainder of the compensations awarded by the Court to the next of kin of the victims.
} 
tion of American States have an obligation to abide by the decisions of its organs, the Commission's recommendations are not decisions and are therefore not legally binding. ${ }^{35}$ In addition, the Inter-American Court has held that such recommendations do not have the character of an obligatory judicial decision for which the failure to comply would generate State responsibility. ${ }^{36}$ Finally, individuals do not have direct access to the Inter-American Court. Only States and the Commission do. ${ }^{37}$ Victims of violations can appear on their own behalf, but only once the application made by the Commission for the referral of a case has been accepted by the Court. ${ }^{38}$ They cannot directly request the Court to hear their case and at any rate, the Court will not hear the case if its examination by the Inter-American Commission has not been completed. ${ }^{39}$ These requirements subject the determination of a victim's fate to the vagaries of institutional inactivity, indecision, and bottlenecks.

\section{Recommendation}

There should be put in motion a machinery to boost the publicity of human rights violations in the region. The negative publicity may demean the standing of the country concerned in the international community and operate as a deterrent to potential violators. The strategy of naming and shaming and the embarrassment that stem from it may prove to be a useful deterrent against human rights abuse. Again, international financial institutions, aids and donor agencies should blacklist countries with very poor human rights reputation. Again, to strengthen the enforcement machinery of the human rights regime, membership of the inter-American Court and Commission should be made full time with adequate remuneration. Furthermore, the Commission should be able to transmit a case directly to the Court whether or not the party concerned has ratified the American Convention. Similarly, a specific mechanism should be created under Article 65 of the American Convention to superintend the enforcement of the judgment of the Inter-American Court of Human Rights. Inadequate enforcement of the judgment of the Court emboldens countries that violate human rights and this need to be rectified. Finally, it is suggested that Article 61 of the American Convention be modified to expand access to the Court to include individuals or non-governmental elements who wish to bring a direct complaint to the Court. These recommendations if carried through would secure for the inter-American system a solid footing within the larger scope of international human rights law. A free and smooth access to the court would encourage the compilation and submission of complaints and ultimately minimize the rate of

\footnotetext{
${ }^{35}$ This is the general rule under international law. It ought however be noted that by complying with the recommendations of the Commission, OAS member States may contribute to the development of customary norms of international law. Recommendations of the Commission may rely on such binding norms.

${ }^{36}$ See Caballero Delgado and Santana vs. Costa Rica, Judgment of December 8, 1995, Ser. A No. 22 at para. 67. Accessed at http://www.wcl.american.edu/hrbrief/07/2newsasystem.cfm on 10/5/2010.

${ }^{37}$ Article 61 American Convention.

${ }^{38}$ Article 23 Rules of Procedure of Inter-American Court.

${ }^{39}$ Article 61 (2) American Convention.
} 
human rights abuse because of the certainty of trial and enforcement of judgment.

\section{Conclusion}

There are three basic human rights instruments under the Inter-American System, namely, the Charter of the Organization of American States; the American Declaration of the Rights and Duties of Man; and the American Convention on Human Rights. Going by international best practices, these instruments have recorded significant landmarks. But there still remain gaping holes to bridge in order to improve the operational efficiency of the human rights regime. These and other issues have been carefully evaluated in the paper.

\section{Conflicts of Interest}

The author declares no conflicts of interest regarding the publication of this paper.

\section{References}

Barsh, R. (1986). Indigenous Peoples: An Emerging Object of International Law. American Journal of International Law, 80, 369-385. https://doi.org/10.2307/2201975

Buergenthal, T. (1995). International Human Rights in a Nutshell, ( ${ }^{\text {nd }}$ Edition). Minnesota: West Publishing Co.

Caron, C. (2004). News from the Inter-American System. Human Rights BRIEF, VII.

Dowrick, F. E. (ed.) (1979). Human Rights Problems, Prospects and Texts. Westmead, United Kingdom: Saxon House.

Ezejiofor, G. (2005). The Development of the Concept of Human Rights: Definition and Philosophical Foundations. In O. Okpara, Ed., Human Rights Law and Practice (Vol. 1). Enugu: Chenglo Ltd.

Robinson, W. G. (2000). Human Development and Human Rights. Oxford: Oxford University Press.

Schwelb, E. (1964). Human Rights and the International Community. Chicago: Quadrangle Books.

Shaw, M. N. (1997). International Law (4 ${ }^{\text {th }}$ Edition). Cambridge: Cambridge University Press.

Umozurike, U. O. (2004). The Concept of Human Rights. Ohafia: Akanu Ohafia Co-Operative and Rural Development Centre Lecture Series.

Umozurike, U. O. (2005). Introduction to International Law ( $3^{\text {rd }}$ Edition). Ibadan: Spectrum Books Ltd. 